\title{
KETERLIBATAN ORANG TUA DALAM INTERVENSI GANGGUAN KECEMASAN ANAK BARU MASUK SEKOLAH
}

\author{
Rafika Tasya Nesia ${ }^{1}$, Farida Kurniawati ${ }^{2}$ \\ ${ }^{1,2}$ Fakultas Psikologi, Universitas Indonesia \\ Jl. Lkr. Kampus Raya Jl. Mawar No.5 3 8, Pondok Cina, Kecamatan Beji, Kota Depok, Jawa Barat 16424 \\ E-mail: rafika.tasya@gmail.com
}

\begin{abstract}
ABSTRAK
Faktor umum penyebab terjadinya gangguan kecemasan pada anak, terutama pada anak yang baru memasuki lingkungan sekolah, merupakan pengaruh dari keluarga. Pemberian intervensi yang dilakukan sejak dini dapat menangani gangguan kecemasan ataupun mencegah gejala kecemasan menjadi gangguan yang lebih serius. Melibatkan orang tua dalam intervensi anak dengan gangguan kecemasan dirasa dapat lebih membantu anak menuju perkembangan yang lebih positif dan membantu orang tua dalam mengubah perilaku ketika menghadapi masalah anaknya dan masalahnya sendiri. Tujuan dari kajian literatur ini adalah untuk mengetahui gambaran keterlibatan orang tua dalam intervensi anak dengan gangguan kecemasan yang timbul pada usia baru memasuki lingkungan sekolah, yaitu 6 hingga 7 tahun. Melalui alat pencarian riset elektronik EBSCOhost Research Databases pada database Academic Search Complete, didapatkan 4 artikel jurnal yang sesuai dengan kriteria untuk mencapai tujuan penelitian. Berdasarkan hasil analisis, ditemukan bahwa dari keempat jenis program intervensi yang berbeda, menunjukkan hasil yang signifikan dan efektif dalam menurunkan tingkat gangguan kecemasan yang dialami anak saat melibatkan orang tua khususnya Ibu. Keterlibatan orang tua dalam intervensi juga dirasa lebih efektif daripada terapi individu jika orang tua memiliki gangguan kecemasan dan dapat meningkatkan kualitas fungsi keluarga.
\end{abstract}

Kata kunci: anak; gangguan kecemasan; intervensi; keterlibatan orang tua

\section{PARENTAL INVOLVEMENT IN ANXIETY DISORDER INTERVENTION AN EARLY SCHOOL AGE CHILDREN}

\begin{abstract}
A common factor causing anxiety disorders in children, especially in children who have just entered the school environment, is the influence of the family. Early intervention can treat anxiety disorders or prevent anxiety symptoms to become more severe disorders. Involving parents in the intervention of children with anxiety disorders is felt to be more helpful in moving children towards more positive development and assist parents in changing behavior when facing their child and their own problem. The purpose of this literature review is to find outthe description of the involvement of parents in the intervention of children with anxiety disorders that arise at the age of just entering the school environment, which is 6 to 7 years old. Through the EBSCOhost Research Databases electronic search tool on the Academic Search Complete database, 4 journal articles were found fit to the criteria for achieving research purpose. Based on the analytical results, it's found that all of the four different types of intervention programs, showed significant and effective results in reducing the level of anxiety disorders experienced by children when involving parents, especially mothers. Parental involvement in interventions is also felt to be more effective than individual therapy if parents have anxiety disorders and can improve the quality of family functioning.
\end{abstract}

Keywords: child; anxiety disorder; intervention; parental involvement

\section{PENDAHULUAN}

Usia 6 atau 7 tahun merupakan usia bagi anak untuk memasuki tingkatan sekolah yang lebih tinggi, yaitu sekolah dasar (SD). Undang-undang Permendikbud Nomor 14 Tahun 2018 Pasal 6 mengatur tentang penerimaan peserta didik baru sekolah dasar, yaitu persyaratan calon peserta didik baru kelas 1 (satu) SD berusia 7 (tujuh) tahun atau paling rendah 6 (enam) tahun pada tanggal 1 Juli tahun berjalan. Pratiwi (2018) mengungkapkan bahwa undang-undang ini dibentuk berdasarkan pertimbangan anak yang telah berusia 6 atau 7 tahun memiliki kesiapan dari sisi psikologis, perkembangan kognitif, perkembangan sosial dan emosional, perkembangan fisik dan motorik, serta perkembangan bahasa.

Pada rata-rata usia ini, memasuki kelas satu menandakan bahwa telah terjadi perubahan dari "anak rumah" menjadi "anak sekolah" karena sekolah telah menjadi rumah kedua bagi anak (Santrock, 2011). 
Anak dihadapkan pada peran dan kewajiban baru yang harus mereka hadapi. Anak mengambil peran baru sebagai siswa, berinteraksi dengan teman sebaya dan guru, mengembangkan hubungan baru, serta mengembangkan standar baru untuk menilai diri mereka sendiri (Santrock, 2011). Hal ini dapat menyebabkan anak memiliki rasa cemas saat proses adaptasi berjalan di sekolah. Rasa cemas (anxiety) merupakan perasaan tidak nyaman yang terjadi ketika anak mengantisipasi adanya rasa sakit fisik atau psikologis yang seringkali samar dan sulit diketahui namun selalu dirasakan (Feist, Feist, \& Roberts, 2017; Miller, 2011). Rasa cemas dapat meningkat jika anak tidak memiliki kesiapan dalam menghadapi tuntutan akademis dan tuntuan peran sebagai siswa di sekolah. Freud mengidentifikasi rasa cemas sebagai salah satu sumber konflik atau gangguan psikologis (Miller, 2011).

Kecemasan merupakan bentuk emosi yang adaptif sehingga anak-anak dapat mengatasi manusia, benda, atau kondisi yang membahayakan keselamatan atau kesejahteraan mereka baik secara fisik maupun psikis (Mash \& Wolfe, 2016). Kecemasan menjadi sinyal bagaimana anak-anak akan memberikan respon pada hal-hal tersebut. Meskipun kecemasan itu adalah hal positif namun, jika terlalu berlebihan dan tidak terkendali maka akan menjadi hal negatif. Anak-anak yang mengalami kecemasan berlebihan dikatakan memiliki anxiety disorder (gangguan kecemasan) dimana emosi yang berguna ini akan bekerja melawan diri mereka sendiri (Mash \& Wolfe, 2016). Anxiety disorder adalah sekelompok gangguan yang ditandai dengan kecemasan yang intens dan persisten, ketakutan yang tidak proporsional dengan bahaya nyata yang dialami, dan dapat mengganggu kehidupan sehari-hari (Cisler, Olatunji, Feldner, \& Forsyth, 2010; Kerig, Ludlow, \& Wenar, 2012). Seseorang dengan anxiety disorder menunjukkan karakteristik ketegangan motorik (gelisah \& gemetar), hiperaktif (pusing \& jantung berdebar), dan takut pada harapan dan pikiran (King, 2011). Rasa cemas yang diabaikan dapat menjadi gangguan kecemasan dimana akan menimbulkan tingkah laku yang tidak normal.

Gangguan kecemasan memiliki beberapa kategori dan di antaranya dialami oleh anak yang baru masuk sekolah, yaitu separation anxiety disorder (SAD), specific phobia yang dalam hal ini adalah school phobia, social anxiety disorder (SOC) atau social phobia, dan selective mutism. Gejala-gejala yang ada pada gangguan-gangguan kecemasan tersebut akan berlanjut hingga dewasa jika tidak ditangani sejak dini. Salah satu contoh timbulnya tingkah laku yang tidak normal adalah school refusal (Manurung, 2012). Anak dengan gangguan kecemasan dapat kehilangan teman sebagai akibat dari penolakan berulang mereka untuk berpartisipasi dalam kegiatan yang jauh dari rumah seperti sekolah. Walaupun anak dengan jenis gangguan kecemasan tertentu dapat menjadi cukup terampil secara sosial dan bergaul dengan orang lain, namun performa sekolah mereka mungkin akan menurun akibat dari ketidakhadiran yang sering terjadi, bahkan dapat mengakibatkan tidak naik kelas (Mash \& Wolfe,
2016). Gejala yang terbentuk sejak dini berlanjut hingga dewasa pada lebih dari sepertiga anak-anak dan remaja (Mash \& Wolfe, 2016). Sebagai orang dewasa, anak-anak ini mungkin akan mengalami kesulitan memiliki hubungan dengan orang lain seperti tidak pernah menikah atau bercerai, gangguan kecemasan lain dan masalah kesehatan mental khususnya gangguan panik dan depresi, dan gangguan fungsional pada kehidupan sosial dan pribadi (Milrod dkk., 2014)

Gangguan kecemasan pada anak yang berkaitan dengan sekolah merupakan hasil interaksi dari sejumlah faktor yang umumnya merupakan pengaruh dari keluarga. Praktik pengasuhan seperti penolakan, kontrol berlebihan, proteksi berlebihan, dan mencontohkan perilaku cemas telah diidentifikasi sebagai kontributor gejala dan gangguan kecemasan di masa kecil (Edwards, Rapee, \& Kennedy, 2010). Secara umum, hasil penelitian pada keluarga secara konsisten menunjukkan adanya hubungan antara gangguan kecemasan pada anak dan gangguan kecemasan pada anggota keluarga terdekat. Anak-anak dari orang tua dengan gangguan kecemasan akan sekitar 5 kali lebih berisiko mengalami gangguan kecemasan daripada anak-anak dengan orang tua tanpa riwayat gangguan kecemasan (Gregory \& Eley, 2011; Lamb, Middeldorp, van Beijsterveldt, Bartels, van der Aa, Polderman, \& Boomsma, 2010; Murray, Creswell, \& Cooper, 2009). Dari hasil studi yang sama juga menunjukkan bahwa sekitar sepertiga atau lebih dari varian dalam gejala kecemasan masa kecil tercatat disebabkan oleh pengaruh genetik.

Hubungan orang tua dengan anak memiliki dampak yang besar pada kesejahteraan psikososial anak (Cummings, Goeke-Morey, \& Papp, 2003, dalam Özyurt, Dinsever, Çaliskan, \& Evgin, 2018). Anak yang tidak memiliki hubungan yang hangat, positif, insecure attachment, disiplin yang ketat dan tidak konsisten, pengawasan yang tidak memadai, konflik keluarga, serta psikopatologi orang tua (terutama depresi pada Ibu) dapat meningkatkan masalah emosi dan perilaku pada anak (Cummings dkk., 2003, dalam Özyurt dkk., 2018). Anak dengan gangguan kecemasan membutuhkan penanganan dalam mencegah implikasi terhadap perkembangan gangguan kecemasan yang lebih serius (Lim, Mansor, \& Madon, 2015). Sebagai usaha dalam menunjang perkembangan yang positif pada siswa, pihak sekolah merasa bahwa keterlibatan orang tua dalam intervensi anak dengan gangguan kecemasan sangat bermanfaat (Puspitasari \& Wati, 2012). Salah satu contoh intervensi yang melibatkan orang tua adalah program Parent-School partnership. Program ini merupakan salah satu intervensi pencegahan pada anak dalam mengalami gangguan kecemasan ataupun mencegah gejala kecemasan yang telah dimiliki anak agar tidak berkembang menjadi gangguan yang lebih serius (Puspitasari \& Wati, 2012). Alasan lain yang mana program intervensi anak dengan gangguan kecemasan melibatkan orang tua karena dianggap dapat lebih membantu anak dalam intervensi dan dapat mengubah perilaku orang tua menghadapi masalah anaknya dan masalah orang tua itu sendiri (Thulin dkk., 2014). 
Berdasarkan pembahasan diatas, penelitian yang berupa kajian literasi ilmiah ini bertujuan untuk mengumpulkan hasil studi ilmiah baik kuantitatif maupun kualitatif berkaitan dengan keterlibatan orang tua dalam intervensi anak dengan gangguan kecemasan yang timbul pada usia baru memasuki lingkungan sekolah, yaitu 6- 7 tahun.

\section{METODE}

\section{Prosedur Pencarian}

Artikel jurnal yang diikutsertakan ke dalam penelitian ini adalah artikel yang membahas mengenai intervensi gangguan kecemasan anak baru masuk sekolah yang melibatkan orang tua. Anak baru masuk sekolah yang dimaksud adalah anak pada usia 6-7 tahun dan menunjukkan gejala kecemasan bahkan gangguan kecemasan. Jenis gangguan kecemasan dan tingkat kecemasan tidak dibatasi oleh peneliti. Pembahasan intervensi dalam penelitian ini adalah jenis-jenis intervensi apa saja yang dapat dilakukan pada anak yang juga melibatkan orang tua dalam prosesnya dan bagaimana efektivitas dari intervensi tersebut.

Proses pencarian sistematis dilakukan menggunakan alat pencarian riset elektronik EBSCOhost Research Databases pada database Academic Search Complete melalui Perpustakaan Universitas Indonesia akses jarak jauh terhadap artikelartikel yang telah diterbitkan dalam rentang bulan Januari 2009 hingga Oktober 2019. Alasan dilakukannya pembatasan pada 10 tahun terakhir adalah untuk mendapatkan kebaruan dalam penelitianpenelitian terkait intervensi anak dengan gangguan kecemasan yang timbul pada usia baru memasuki lingkungan sekolah, yaitu 6- 7 tahun di mana orang tua ikut terlibat dalam intervensi tersebut. Pencarian dibatasi pada artikel-artikel jurnal berbahasa Inggris, dapat diakses penuh (full text), dan sudah melalui proses peninjauan ulang secara akademik (scholarly peer reviewed journals). Kombinasi dari kata kunci yang digunakan dalam pencarian pada database EBSCOhostadalah: 'Parental Involvement' AND 'Intervention' AND 'Anxiety Disorder' AND 'Children'. Pencarian menggunakan kombinasi kata kunci di atas menghasilkan 85 penelitian ilmiah sebelum dilakukan seleksi lebih lanjut terkait dengan kesesuaian kriteria yang akan digunakan.

\section{Prosedur Pemilihan}

Proses seleksi artikel jurnal dari hasil pencarian database yang akan diikutsertakan dan dieliminasi pada analisa lanjutan terdiri atas: (1) identifikasi judul, nama peneliti, dan abstrak; (2) screening artikel jurnal, terutama pada bagian tujuan penelitian, metode, dan hasil; (3) penilaian studi-studi yang akan diseleksi pada analisa dan dieliminasi; (4) pemberian keputusan pada studi-studi yang akan diseleksi atau dieliminasi. Untuk mendapatkan artikel jurnal yang dibutuhkan, setiap studi harus memenuhi kriteria mengenai adanya keterlibatan orang tua dalam intervensi anak dengan gangguan kecemasan pada usia baru memasuki lingkungan sekolah, yaitu usia 6 atau 7 tahun.

Setelah melakukan identifikasi, screening, penilaian, dan menerapkan kriteria seleksi, 81 referensi artikel jurnal tidak diikutsertakan karena tidak berhubungan dengan tinjauan yang dilakukan. Studistudi ini tidak memenuhi kriteria inklusi karena sejumlah alasan (rincian pada Tabel 1): misalnya melibatkan anak berkebutuhan khusus, gangguan pada remaja, dan kesehatan fisik $(\mathrm{N}=20)$. Selain itu, artikel jurnal lainnya dieliminasi karena tidak memenuhi kriteria seleksi: tiga studi hanya melakukan intervensi pada orang tua tanpa adanya intervensi pada anak, tiga studi fokus pada pembahasan anxiety disorder tanpa adanya intervensi, dan tiga belas studi menggunakan partisipan anak dengan usia yang jauh lebih muda dan lebih tua yang tidak menjadi kriteria usia anak yang digunakan dalam penelitian ini (usia 6-7 tahun). Hasil dari proses pencarian pada database EBSCOhost diperlihatkan dalam diagram pada Gambar 1.

Tabel 1. Alasan Penolakan Artikel Jurnal yang Tidak Diikutsertakan dalam Analisis

\begin{tabular}{|c|c|c|}
\hline No & $\overline{\text { Alasan }}$ & Jumlah \\
\hline 1 & Penelitian meta analisis & 5 \\
\hline 2 & $\begin{array}{l}\text { Melibatkan partisipan yang jauh lebih } \\
\text { muda dan lebih tua }\end{array}$ & 13 \\
\hline 3 & $\begin{array}{l}\text { Fokus pada pembahasan anxiety disorder } \\
\text { tanpa ada intervensi }\end{array}$ & 3 \\
\hline 4 & $\begin{array}{l}\text { Fokus pada pencegahan gangguan } \\
\text { kecemasan tanpa keterlibatan orang tua }\end{array}$ & 3 \\
\hline 5 & $\begin{array}{l}\text { Melakukan intervensi hanya pada orang } \\
\text { tua }\end{array}$ & 3 \\
\hline 6 & $\begin{array}{l}\text { Melibatkan anak berkebutuhan khusus, } \\
\text { gangguan pada remaja, dan kesehatan } \\
\text { fisik (penyakit jantung) }\end{array}$ & 20 \\
\hline 7 & $\begin{array}{l}\text { Gangguan depresi pada Ibu yang akan } \\
\text { melahirkan dan baru melahirkan }\end{array}$ & 12 \\
\hline 8 & $\begin{array}{l}\text { Penelitian terkait melihat gejala } \\
\text { kecemasan yang ditunjukkan pada usia } \\
\text { tertentu }\end{array}$ & 2 \\
\hline 9 & Gangguan kecemasan pada orang tua & 4 \\
\hline 10 & $\begin{array}{l}\text { Penelitian terkait mencari faktor-faktor } \\
\text { penyebab kecemasan pada anak }\end{array}$ & 11 \\
\hline 11 & $\begin{array}{l}\text { Penelitian terkait rintangan dalam } \\
\text { mencari bantuan pada kecemasan anak }\end{array}$ & 1 \\
\hline 12 & $\begin{array}{l}\text { Fokus pada analisa penyebab di masa } \\
\text { kecil terkait gangguan sosial di masa } \\
\text { dewasa }\end{array}$ & 1 \\
\hline \multirow[t]{2}{*}{13} & Artikel tidak lengkap & 3 \\
\hline & Total & 81 \\
\hline
\end{tabular}




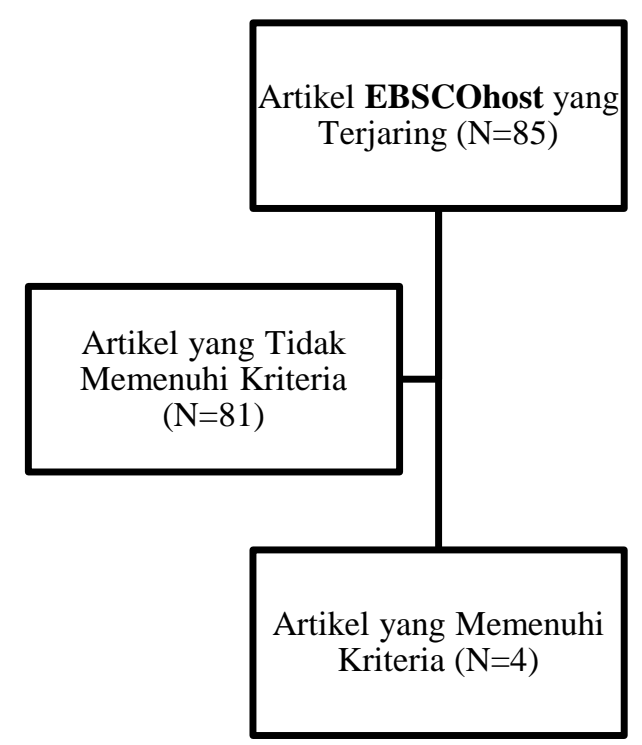

Gambar 1. Diagram alur dari proses pemilihan artikel jurnal

\section{Karakteristik Partisipan}

Partisipan yang dipilih dalam artikel penelitian adalah orang tua dengan anaknya yang memiliki anxiety disorder. Jenis anxiety disorder yang dialami anak itu sendiri adalah separation anxiety disorder (SAD), generalized anxiety disorder (GAD), social phobia (SoC), specific phobia, maupun diagnosa ganda dari gangguan kecemasan (Cartwright-Hatton dkk., 2011; Bilwani \& Gupta, 2015; Yen dkk., 2017). Pada penelitian Özyurt dkk. (2018), tidak ada penjelasan mengenai jenis anxiety disorder yang dialami anak secara spesifik. Jenjang pendidikan anak yang diambil sebagai partisipan di dalam penelitian dimulai dari usia prasekolah hingga sekolah dasar, yaitu usia 3 hingga 12 tahun (Cartwright-Hatton dkk., 2011; Bilwani \& Gupta, 2015; Yen dkk., 2017; Özyurt dkk., 2018).

\section{HASIL DAN PEMBAHASAN}

\section{Hasil}

Hasil pencarian memberikan studi mengenai jenis intervensi yang digunakan pada anak dengan anxiety disorder dan melibatkan orang tua khususnya Ibu. Intervensi-intervensi yang digunakan merupakan hasil modifikasi dari jenis intervensi yang sudah ada karena disesuaikan dengan jenis gangguan yang dialami anak dan usia anak sebagai partisipan dalam penelitian. Dari keempat jenis intervensi yang berbeda, semuanya menunjukkan hasil yang signifikan dan efektif dalam menurunkan tingkat gangguan kecemasan yang dialami anak saat melibatkan orang tua khususnya Ibu. Data pada studi penelitian ilmiah yang terseleksi terangkum pada Tabel 1 dengan data 4 studi.

\section{Pembahasan}

Tinjauan sistematis terhadap literatur ilmiah yang sesuai dengan kriteria terbit pada tahun 2011 sampai dengan tahun 2018 bertujuan untuk memberikan gambaran mengenai keterlibatan orang tua dalam intervensi anak dengan gangguan kecemasan pada usia baru memasuki lingkungan sekolah, yaitu usia 6 atau 7 tahun. Gangguan kecemasan adalah salah satu masalah psikis yang umum pada anak-anak. Pemberian intervensi sangat penting diberikan pada anak di tahap awal gejala kecemasan itu muncul. Intervensi yang diberikan sejak awal dengan hasil yang efektif dapat meminimalkan morbiditas di masa dewasa (Bilwani \& Gupta, 2015).

Pada usia 6- 7 tahun, anak-anak mengalami perkembangan dalam bahasa, kognisi, emosi, dan perilaku sosial yang dapat mempengaruhi terjadinya gejala anxiety disorder. Hubungan orang tua dengan anak juga memiliki dampak yang besar pada kesejahteraan psikososial anak (Cummings, GoekeMorey, \& Papp, 2003, dalam Özyurt, Dinsever, Çaliskan, \& Evgin, 2018). Dari keempat penelitian menunjukkan bahwa anak yang tidak memiliki hubungan yang hangat, positif, insecure attachment, disiplin yang ketat dan tidak konsisten, pengawasan yang tidak memadai, konflik keluarga, sertapsikopatologi orang tua (terutama depresi pada Ibu) dapat meningkatkan masalah emosi dan perilaku pada anak (Bilwani \& Gupta, 2015; Cartwright-Hatton dkk., 2011; Özyurt dkk., 2018; Yen dkk., 2017). Hal ini menjadikan keterlibatan keluarga dalam perkembangan anak menjadi perhatian khusus dalam pemberian intervensi karena peran pola pengasuhan orang tua tertentu dapat menimbulkan rasa cemas yang dapat berkembang menjadi anxiety disorder. Banyaknya faktor dalam keluarga yang menyebabkan gangguan kecemasan pada anak menjadi gambaran pentingnya pengasuhan positif dalam membesarkan anak yang semakin meningkat.

Keterlibatan keluarga dalam pemberian intervensi pada anak dengan gangguan kecemasan sering direkomendasikan karena peran pola pengasuhan orang tua tertentu dapat memelihara gejala kecemasan pada anak. Salah satu contohnya adalah perilaku proteksi berlebihan oleh Ibu yang merupakan penyebab terjadinya gejala SAD pada anak-anak (Bilwani \& Gupta, 2015). Terdapat kemungkinan bahwa peran Ibu yang menghalangi anak untuk mengeksplorasi dan terlalu melindungi anak-anak mereka akan mengarah pada persepsi diri anak tentang ketidakmampuan karena mengurangi peluang bagi anak untuk menghadapi dan mengatasi situasi yang asing (Bilwani \& Gupta, 2015). Selain itu, penelitian terbaru menunjukkan bahwa reaksi psikososial orang tua dan anak berkorelasi satu sama lain dan stres yang dialami orang tua mempengaruhi kesehatan anak secara negatif. Stres yang dialami orang tua membentuk strategi koping yang tidak tepat pada orang tua yang dapat merusak hubungan antara anak dan orang tua, dan hal ini dapat menyebabkan pengabaian dan penganiayaan pada anak (Özyurt dkk., 2018). Strategi koping pada orang tua memainkan peran penting dalam pengembangan perilaku dan sikap orang tua terhadap anak-anak. Orang tua yang meningkatkan keterampilan coping menunjukkan pengasuhan yang lebih positif. Dalam penelitian Özyurt dkk. (2018) ditemukan bahwa Triple $P$ berkontribusi pada penurunan perilaku child 
maltreatment pada orang tua dan mengurangi masalah perilaku dan emosional anak-anak serta memperkuat strategi koping pada ibu. Pemberian program intervensi dengan melibatkan orang tua akan memfasilitasi keterampilan orang tua dalam mengatasi stres yang berkontribusi pada perkembangan psikososial anakanak (Cartwright-Hatton dkk., 2011; Bilwani \& Gupta, 2015; Yen dkk., 2017; Özyurt dkk., 2018).

Tujuan dari program intervensi yang melibatkan orang tua adalah meneliti peran orang tua dalam perannya sebagai penyebab masalah perilaku pada anak, mengidentifikasi kemungkinan penyebabnya, dan membantu orang tua untuk menentukan tujuan dalam perubahan perilaku. Ketika anak-anak diberikan lingkungan pengasuhan yang hangat, tenang, konsisten, dengan reinforcement yang positif pada perilaku untuk meningkatkan kepercayaan diri, kecemasan akan berkurang (Cartwright-Hatton dkk., 2011). Selain itu, didapatkan juga hasil berupa efek positif pada ibu dengan depresi dan peningkatankualitas hubungan antara pasangan dari penerapan program pengasuhan. Dari keempat penelitian dapat dilihat bahwa dengan menerapkan jenis intervensi yang berbeda namun tetapmelibatkan orang tua khususnya Ibu dapat menurunkan angka kecemasan pada anak (CartwrightHatton dkk., 2011; Bilwani \& Gupta, 2015; Yen dkk., 2017; Özyurt dkk., 2018).

\section{SIMPULAN}

Pemberian intervensi pada anak-anak yang memiliki gejala anxiety disorder sangat penting. Lebih penting lagi jika intervensi ini melibatkan orang tua, khususnya Ibu, di mana keluarga merupakan faktor dalam angka terjadinya anxiety disorder pada anak usia 6- 7 tahun. Tujuan utama pemberian intervensi adalah untuk mengurangi durasi dan tingkat keparahan gejala terkait anxiety disorder dan untuk mencegah kekambuhan dan psikopatologi di tahapan perkembangan selanjutnya jika memungkinkan. Pemberian intervensi sejak dini dengan langkah yang efektif dapat meminimalkan angka kesakitan (morbiditas) di masa dewasa. Tinjauan sistematis tentang gambaran intervensi berbasis keluarga untuk anxiety disorder menunjukkan bahwa intervensi ini setidaknya sama efektifnya dengan intervensi individu (Bilwani \& Gupta, 2015). Intervensi ini dirasa lebih efektif daripada terapi individu dalam kasus di mana orang tua juga memiliki gangguan kecemasan dan lebih efektif daripada intervensi individu dalam meningkatkan kualitas fungsi keluarga.

\section{Batasan Penelitian dan Saran}

Berdasarkan pembahasan di atas, penelitian yang berupa kajian literatur ilmiah ini bertujuan dalam memberikan gambaran umum secara sistematis mengenai keterlibatan orang tua dalam intervensi anak dengan gangguan kecemasan pada usia baru memasuki lingkungan sekolah, yaitu usia 6 atau 7 tahun ini memiliki keterbatasan. Studi-studi melalui sintesis ini belum dapat digeneralisasi sebagai gambaran umum yang lebih luas. Fokus studi yang hanya merujuk pada penelitian dengan partisipan yang melibatkan anak usia 6 atau 7 tahun membuat total studi yang terseleksi menjadi sangat sedikit. Selain itu, pengambilan artikel jurnal dalam penelitian ini hanya dilakukan pada satu database sehingga kemungkinan besar terdapat beberapa artikel jurnal yang sesuai dengan topik penelitian ini selain pada alat pencarian riset elektronik EBSCOhost Research Databases. Penggunaan keyword juga dapat mempengaruhi hasil pencarian. Pada penelitian ini tidak dilakukan pencarian spesifik pada jenis anxiety disorder seperti menambahkan data pencarian pada keyword separation anxiety disorder (SAD), specific phobia yang dalam hal ini adalah school phobia, social anxiety disorder (SOC) atau social phobia, dan selective mutism yang dapat terjadi pada usia anak yang baru memasuki lingkungan sekolah, yaitu usia 6 atau 7 tahun.

Di samping keterbatasan yang ada, kajian literatur ilmiah ini dapat memberikan gambaran beberapa program atau teknik intervensi yang dapat diterapkan pada anak yang memiliki gejala-gejala kecemasan hingga gangguan kecemasan. Program-program hasil temuan pada keempat artikel jurnal tersebut juga dapat memberikan gambaran kecil pentingnya melibatkan orang tua dalam intervensi anak dengan gangguan kecemasan. Penelitian-penelitian selanjutnya dapat mempertimbangkan kajian literatur mengenai efektivitas keterlibatan orang tua dalam intervensi pada anxiety disorder pada periode usia tertentu untuk membandingkan hasil intervensi di setiap jenjang usia atau program intervensi lainnya yang mungkin dapat memberikan dampak yang berbeda pada lingkungan sosial yang berbeda.

\section{DAFTAR PUSTAKA}

Bilwani, R., \& Gupta, M. (2015). A model for management for young children aged 3-7 years with Separation Anxiety Disorder. Journal of Indian Association for Child \& Adolescent Mental Health, 11(1), 32-55.

Cartwright-Hatton, S., McNally, D., Field, A. P., Rust, S., Laskey, B., Dixon, C., ... Woodham, A. (2011). A new parenting-based group intervention for young anxious children: Results of a randomized controlled trial. Journal of the American Academy of Child and Adolescent Psychiatry, 50(3), 242251.

Cisler, J. M., Olatunji, B. O., Feldner, M. T., \& Forsyth, J. P. (2010). Emotion regulation and the anxiety disorders: An integrative review. Journal of Psychopathology and Behavioral Assessment, 32(1), 68-82.

Edwards, S. L., Rapee, R. M., \& Kennedy, S. (2010). Prediction of anxiety symptoms in preschool-aged children: examination of maternal and paternal perspectives. Journal of Child Psychology and Psychiatry, 51(3), 313-321.

Feist, J., Feist, G. J., \& Roberts, T. A. (2017). Teori kepribadian (8th ed.). Jakarta: Salemba Humanika. 
Gregory, A. M., \& Eley, T. C. (2011). The genetic basis of child and adolescent anxiety. In W. K. Silverman \& A. Field (Eds.), Anxiety disorders in children and adolescents: Research, assessment, and intervention (2nd ed., pp. 161-178). Cambridge: Cambridge University.

Kemendikbud. (2018). Permendikbud Nomor 14 Tahun 2018 Pasal 6 Tentang Penerimaan Peserta Didik Baru Sekolah Dasar. Jakarta: Kemendikbud.

Kerig, P. K., Ludlow, A., \& Wenar, C. (2012). Developmental psychopathology (6th ed.). New York: McGraw-Hill Education.

King, L.A. (2011). The science of psychology (2nd ed.). New York, NY: McGraw-Hill.

Lamb, D. J., Middeldorp, C. M., van Beijsterveldt, C. E., Bartels, M., van der Aa, N., Polderman, T. J., \& Boomsma, D. I. (2010). Heritability of anxiousdepressive and withdrawn behavior: age-related changes during adolescence. Journal of the American Academy of Child \& Adolescent Psychiatry, 49(3), 248-255.

Manurung, N. (2012). School refusal pada anak sekolah dasar. Jurnal Psikologi Undip, 11(1), 83-92.

Mash, E. J. \&Wolfe, D. A. (2016). Abnormal child psychology (6th ed.). Boston: Cengage Learning.

Miller, P. H. (2011). Theories of developmental psychology (5th ed.). New York: Worth Publishers.

Milrod, B., Markowitz, J. C., Gerber, A. J., Cyranowski. J., Altemus, M., Shapiro, T., Hofer, M., Glatt, C. (2014). Childhood separation anxiety and the pathogenesis and treatment of adult anxiety. American Journal of Psychiatry, 171, 34 43.

Murray, L., Creswell, C., \& Cooper, P. J. (2009). The development of anxiety disorders in childhood: An integrative review. Psychological Medicine, 39(9), 1413-1423. https://doi.org/10.1017/S0033291709005157

Özyurt, G., Dinsever, Ç., Çalişkan, Z., \& Evgin, D. (2018). Can positive parenting program (Triple P) be useful to prevent child maltreatment? Indian Journal of Psychiatry, 60(3), 286.

Pratiwi, W. (2018). Kesiapan anak usia dini memasuki sekolah dasar. TADBIR: Jurnal Manajemen Pendidikan Islam, 6(1), 1-13.

Puspitasari, I., \& Wati, D. E. (2012). Strategi parentschool partnership: Upaya preventif separation anxiety disorder pada anak usia dini. Yaa Bunayya: Jurnal Pendidikan Anak Usia Dini, 2(1), 49-60.

Santrock, J. W. (2011). Child development (13th ed.). New York, NY: McGraw-Hill.

Thulin, U., Svirsky, L., Serlachius, E., Andersson, G., \& Öst, L. G. (2014). The effect of parent involvement in the treatment of anxiety disorders in children: A meta-analysis. Cognitive Behaviour Therapy, 43(3), 185-200. https://doi.org/10.1080/16506073.2014.923928.

Yen, C. F., Chen, Y. M., Cheng, J. W., Liu, T. L., Huang, T. Y., Wang, P. W., Yang, P., \& Chou, W. J. (2014). Effects of cognitive-behavioral therapy on improving anxiety symptoms, behavioral problems and parenting stress in Taiwanese children with anxiety disorders and their mothers. Child Psychiatry and Human Development, 45(3), 338-347. https://doi.org/10.1007/s10578-013-0403-9

Lim, Y. J., Mansor, M., \& Madon, Z. (2015). Play therapy for anxiety and stress problems among nursery School children in malaysia. Australian Journal of Basic and Applied Sciences, 9(26), 4955 . 